\title{
Single nucleotide polymorphisms
} CrossMark in native South American Atlantic coast
populations of smooth shelled mussels:
hybridization with invasive European Mytilus
galloprovincialis

Małgorzata Zbawicka', María I. Trucco ${ }^{2}$ and Roman Wenne ${ }^{7^{*}}$

\begin{abstract}
Background: Throughout the world, harvesting of mussels Mytilus spp. is based on the exploitation of natural populations and aquaculture. Aquaculture activities include transfers of spat and live adult mussels between various geographic locations, which may result in large-scale changes in the world distribution of Mytilus taxa. Mytilus taxa are morphologically similar and difficult to distinguish. In spite of much research on taxonomy, evolution and geographic distribution, the native Mytilus taxa of the Southern Hemisphere are poorly understood. Recently, single nucleotide polymorphisms (SNPs) have been used to clarify the taxonomic status of populations of smooth shelled mussels from the Pacific coast of South America. In this paper, we used a set of SNPs to characterize, for the first time, populations of smooth shelled mussels Mytilus from the Atlantic coast of South America.
\end{abstract}

Results: Mytilus spp. samples were collected from eastern South America. Six reference samples from the Northern Hemisphere were used: Mytilus edulis from USA and Northern Ireland, Mytilus trossulus from Canada, and Mytilus galloprovincialis from Spain and Italy. Two other reference samples from the Southern Hemisphere were included: M. galloprovincialis from New Zealand and Mytilus chilensis from Chile. Fifty-five SNPs were successfully genotyped, of which 51 were polymorphic. Population genetic analyses using the STRUCTURE program revealed the clustering of eight populations from Argentina (Mytilus platensis) and the clustering of the sample from Ushuaia with M. chilensis from Chile. All individuals in the Puerto Madryn (Argentina) sample were identified as M. platensis $\times$ M. galloprovincialis F2 (88.89\%) hybrids, except one that was classified as Mediterranean M. galloprovincialis. No F1 hybrids were observed.

Conclusions: We demonstrate that M. platensis (or Mytilus edulis platensis) and M. chilensis are distinct native taxa in South America, which indicates that the evolutionary histories of Mytilus taxa along the Atlantic and Pacific coasts differ. M. platensis is endangered by hybridization with M. galloprovincialis that was introduced from Europe into the Puerto Madryn area in Argentina, presumably by accidental introduction via ship traffic. We confirm the occurrence of a native M. chilensis population in southern Argentina on the coast of Patagonia.

\footnotetext{
*Correspondence: rwenne@iopan.gda.pl

1 Institute of Oceanology, Polish Academy of Sciences, Powstańców

Warszawy 55, 81-712 Sopot, Poland

Full list of author information is available at the end of the article
} 


\section{Background}

Correct recognition and identification of species are important to understand the phylogeography of living resources and to ensure the conservation of their biodiversity, their management, sustainable exploitation and traceability. The world production of mussels, Mytilus spp., including exploitation of natural populations and aquaculture, is approximately 1.2 million tons per year [1, 2]. Aquaculture activities include the transfer of spat and live adult mussels between geographic locations, which may result in large-scale changes in the world distribution of Mytilus taxa [3-5]. Mytilus taxa are morphologically similar and difficult to distinguish. Replacement of native species by an invasive taxon can go unnoticed [6]. Individuals from different Mytilus taxa can hybridize in areas where their populations merge and coexist. Hybridization zones have been described in the Danish Straits at the entrance to the Baltic Sea [7-10], on the Atlantic coasts of France [11], Great Britain [12, 13], Greenland [14], and the Atlantic coast of Canada [15]. In addition, the occurrence of doubly uniparental inheritance of mitochondrial DNA (mtDNA), of recombination and introgression can hinder the use of mtDNA analyses for the identification of Mytilus taxa [16-19]. Nuclear DNA markers including genome-wide single nucleotide polymorphisms (SNPs) can indicate geographic origin of interbreeding taxa when hybridization occurs either naturally or results from the introduction of mussels to non-native regions $[14,20]$.

Introduction of Mytilus galloprovincialis, one of the most invasive mussel species, threatens native populations of Mytilus on a global scale [21, 22]. Irrespective of the ecological consequences, including reduction of abundance, introductions of this species have usually been followed by hybridization of M. galloprovincialis with native Mytilus taxa, i.e. Mytilus trossulus on the eastern and western North Pacific coasts [23-26] and native Southern Hemisphere M. galloprovincialis in Australia and New Zealand [27-29]. Michalek et al. [30] reviewed the negative consequences of such hybridization events for the culture of Mytilus in Europe. The introduced M. galloprovincialis interbreeds with native Mytilus edulis are cultivated in Scotland. Northern Hemisphere M. galloprovincialis is also a threat for local farms that are located south of the Gulf of Arauco in Chile and use native populations of Mytilus chilensis from South America [31].

The longest Pacific and Atlantic coastlines that are continuously inhabited by native populations of Mytilus are in South America. South American smooth shelled blue mussels of the genus Mytilus are present on the Atlantic coast of the south of Brazil [32], through Uruguay and Argentina down to Tierra del Fuego $[33,34]$ and around
Cape Horn, and then north into the Pacific to Golfo de Arauco, Chile [35], where they inhabit both intertidal levels and deep banks. The nomenclature for these mussels has been controversial; they were classified based on fossil records and morphological data as Mytilus edulis [34], M. platensis [33, 36-38] or M. chilensis [39]. The native species of Mytilus on the Atlantic coast of South America, i.e. M. platensis was described by d'Orbigny in 1846 [40] using specimens that were collected from the area of Maldonado in Uruguay. The native species on the Pacific coast of South America, i.e. M. chilensis was described by Hupé in 1856 [41] based on specimens found near Concepcion in Chile. Argentine mussels, which were first identified as $M$. platensis, were later synonymised to $M$. edulis or assigned a subspecies rank [38, 42]. Ecological studies also created confusion by assigning specific names, i.e. mussels from the south of Brazil, Uruguay and Buenos Aires province were designated M. platensis [43, 44] and later as M. edulis platensis [45], while those found in Atlantic Patagonian waters and gulfs were variably named, i.e. M. platensis [39], M. chilensis [46] and even M. edulis chilensis [47, 48]. Based on morphological characters such as color, hinge teeth, valve thickness and inferior margin, Castellanos [33] named the Argentine mussel $M$. platensis to differentiate it from the Chilean mussel, M. chilensis. Later, these mussels were considered as subspecies (M. edulis platensis and M. edulis chilensis) since the number of diagnostic characters to assign them to species rank was not sufficient [32, 49]. For fishery management purposes, the names $M$. e. platensis and M. chilensis have been used in Argentina and Chile, respectively.

Aquaculture of Atlantic M. e. platensis was developed in Argentina [50]. Currently, suspended commercial cultures operate in Nuevo Gulf (Puerto Madryn), San Jose Gulf (Isla de los Pájaros) and San Matías Gulf (San Antonio Oeste-Puerto Lobos) [51]. Production of cultured mussels (Mytilus and Aulacomya) in Argentina fell from over 250 tons in 2011 to 11.20 tons in 2016 [52, 53]. Due to economic reasons, $M$. e. platensis is cultivated only in the San Matías Gulf [54] and M. chilensis in the Canal Beagle, Ushuaia [55].

The natural distribution of Chilean mussels ranges from Bahia Concepcion $\left(36^{\circ} 45^{\prime} \mathrm{S}\right)$ to Punta Arenas $\left(53^{\circ} \mathrm{S}\right)$, on the edge of the Strait of Magellan [56, 57]. There have been many studies to clarify their taxonomic status in connection with intensive aquaculture. Various studies using allozymes, nuclear and mitochondrial DNA markers have led to contradictory results, depending on the type of marker used. The presence of Mytilus edulis $[58,59]$ and M. galloprovincialis [35, 56, 57, 60, 61] was reported in Chile, although it is not clear if these are native or introduced populations [62], or even different 
species that may have been included in a single taxon as M. chilensis [63]. Based on morphological and molecular analyses, Toro [64] suggested that $M$. chilensis was a subspecies, M. edulis chilensis, whereas Ouagajjou et al. [65] in a study with microsatellites considered $M$. chilensis to be a valid species. Analysis of mtDNA and nuclear DNA Me15/16 restriction fragment length polymorphisms (RFLP) revealed the occurrence of native $M$. chilensis and the alleged presence of the native Atlantic blue mussel M. edulis, Northern Hemisphere M. galloprovincialis, M. trossulus genes (not individuals) and hybrids (M. chilensis $\times$ M. edulis) in the region of the Strait of Magellan [66]. Recent studies also consider that $M$. chilensis should be named M. edulis platensis [59, 67] or M. platensis [68]. A genetic analysis of Mytilus populations from Argentina and Uruguay using 30 enzyme loci and five DNA markers (Glu-5, Fp-1, Its, CoIII and Mac-1) showed that native Atlantic South American populations are closely related to North Atlantic M. edulis [69]. Because these populations showed characteristic allele frequencies that differed from those of the Northern Hemisphere M. edulis at 10 loci, a taxon name Mytilus edulis platensis was proposed for native mussels from the Atlantic coasts of South America. Consequently, these names have been used in ecology and aquaculture-related publications e.g. [70, 71]. Based on a comparison of single sequences of their mitogenomes, $M$. chilensis and $M$. platensis were placed in the same clade, representing conspecific variants rather than distinct species [72]. In addition, the name $M$. planulatus or M. e. platensis was proposed for all native Mytilus populations in South America [68].

To clarify the taxonomic status of native populations of smooth shelled mussels from the Pacific coast of South America, Larrain et al. [31] used SNP analyses to characterize Mytilus taxa, including a set of reference samples from North America, Europe and New Zealand. According to their results, the Pacific coast South American native mussel is genetically distinct from the reference species $M$. edulis, M. galloprovincialis and M. trossulus, and should be recognised as $M$. chilensis Hupé 1854 [41]. In our work, we used a similar set of SNPs to characterize, for the first time, populations of smooth shelled mussels Mytilus from the coast of South-Western Atlantic and adjacent waters. The aim of our research was to extend the knowledge of the taxonomic status and distribution along the Atlantic coast of South America and Patagonia of native Mytilus taxa and to identify areas where they are potentially endangered by hybridization with the invasive $M$. galloprovincialis.

\section{Methods}

\section{Sample collection and SNP genotyping}

Mytilus spp. samples that consisted of 359 individuals of mixed ages and sizes ( 5 to $50 \mathrm{~mm}$ ) were collected from ten localities in Argentina and one from Chiloe in Chile between 2012 and 2014 (Fig. 1; Table 1). Specimens or tissue samples were stored in $96 \%$ ethanol or at $-70{ }^{\circ} \mathrm{C}$. DNA was isolated from the mantle tissue, using a modified CTAB method according to Hoarau et al. [73]. Eight previously described reference samples were used: $M$. edulis from the Atlantic coast of USA [14] and Northern Ireland [20, 31]; M. galloprovincialis from the Northern Hemisphere, i.e. the Atlantic coast of Spain [20,31] and Mediterranean Sea $[20,29,31]$ and from the Southern Hemisphere, i.e. New Zealand [29]; M. trossulus from Canada, Halifax (based on hybrid index, [14] and $M$. chilensis from Punta Arenas, Chile [31]. Seventy-nine previously identified SNPs were used $[9,14,20,29,31]$. Samples were genotyped using the Sequenom MassARRAY iPLEX genotyping platform [74].

\section{Data analysis}

Arlequin v.3.5.1.2 [75] was used to estimate allele frequencies, the proportion of polymorphic SNPs $\left(P_{O}\right)$, minor allele frequency (MAF), genetic diversity, observed $\left(H_{O}\right)$ and expected $\left(H_{E}\right)$ heterozygosity values for each locus and population. In addition, the statistical significance of the inbreeding coefficient $F_{\text {IS }}(>0)$ was tested by 10,000 permutations of alleles between individuals. Departures from Hardy-Weinberg equilibrium (HWE) were tested by exact test, and significance was determined by Markov chain Monte Carlo simulations. The most informative loci were detected by identifying $F_{\mathrm{ST}}$ outlier loci. The upper limits of the $95 \%$ confidence interval were identified with 20,000 iterations and characterized by estimating the 0.05 and the 0.95 and 0.99 quantiles of the distribution. The false discovery rate (FDR-BY) was applied to correct significance (P) values after multiple testing [76, 77]. Genetic differentiation between populations was determined based on allele frequencies of SNPs using pairwise $F_{\mathrm{ST}}$ values in Arlequin. The $F_{\mathrm{ST}}$ distance measures in the Newick format, which were obtained from SNP allele frequencies data in POPTREEW [78] were used to construct a neighbourjoining (NJ) tree with the MEGA software version 6 [79]. Robustness of relationships was assessed using 10,000 bootstrap replicates. We used two methods for the population structure analyses. First, clustering analysis was carried out with the STRUCTURE v. 2.3.4 software [80, 81]. STRUCTURE was used under a model that assumes admixture, ignores population affiliation and allows for the correlation of allele frequencies between clusters. The admixture model used in this analysis allows individuals to have mixed ancestry, i.e. fractions of the genome can originate from different ancestors. The number of genetic clusters $(K)$ was estimated by computing likelihood over 10 runs for values of $K$ ranging from 1 to the number of 


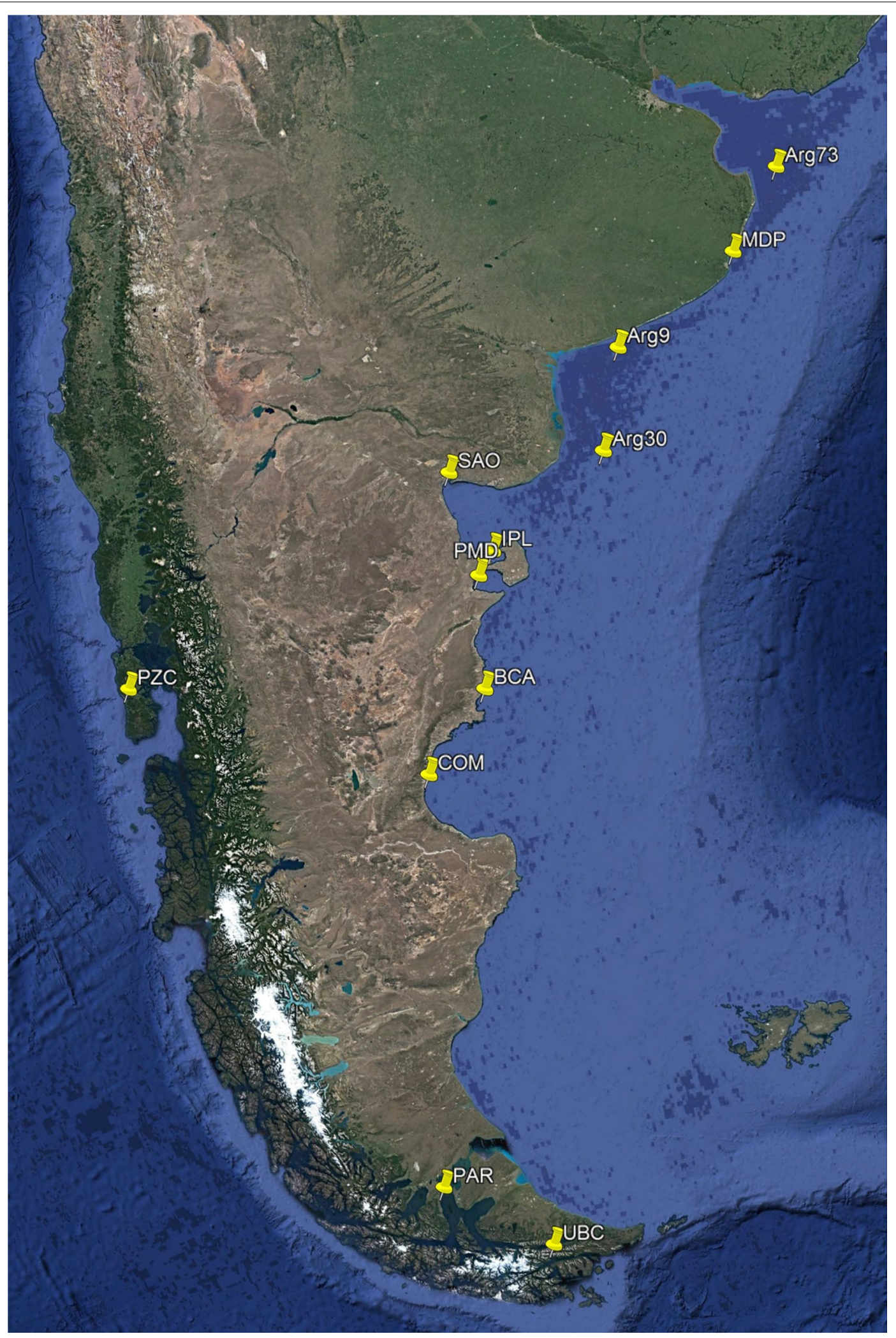

Fig. 1 Location of the 12 populations of Mytilus from Argentina and Chile, South America (Google Earth Pro). Sampling site names and coordinates are in Table 1 


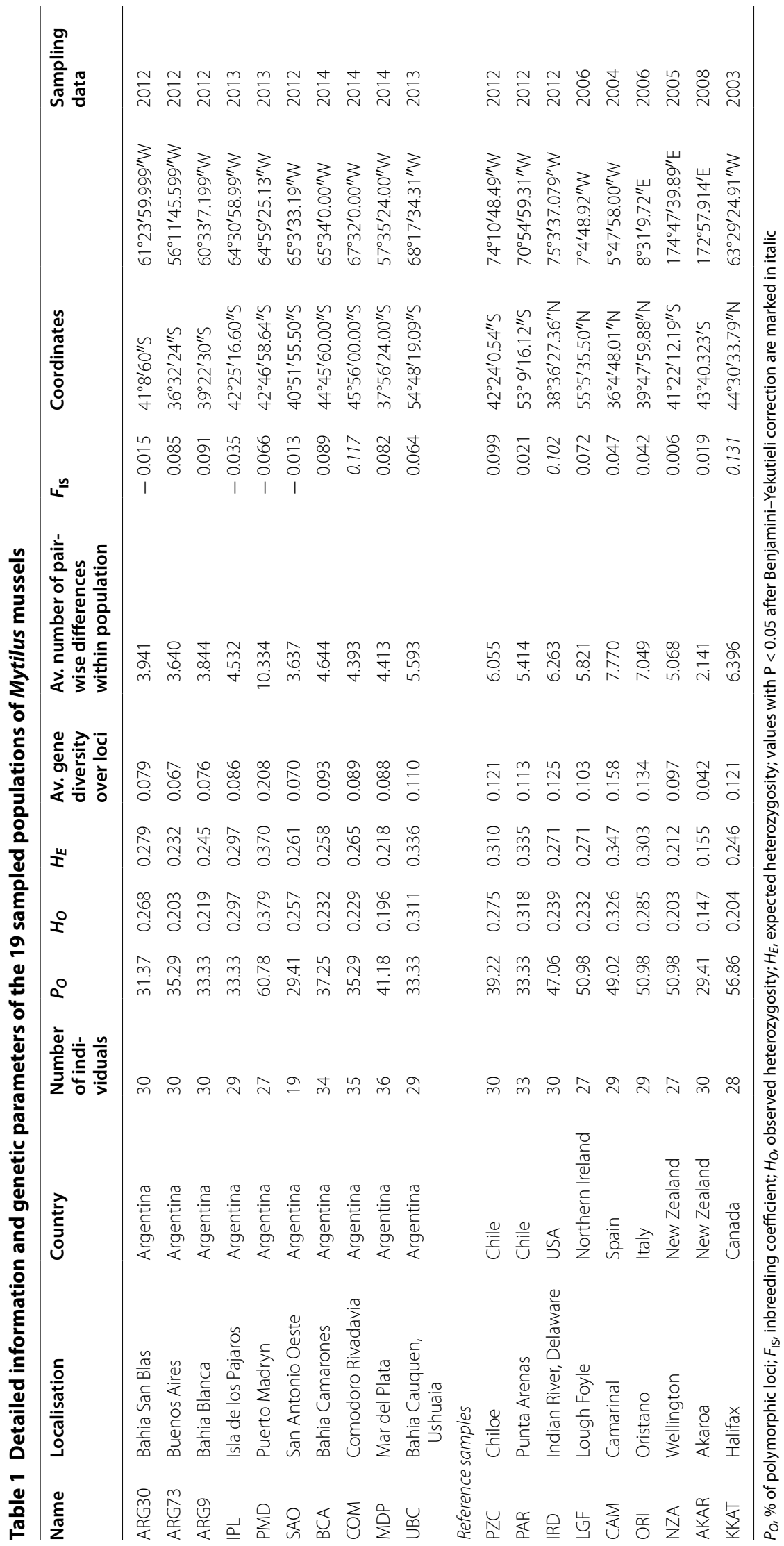


populations studied plus 1 . At the plateau of the graph curve, the value of $K$ captures the main structure of the populations. The best-fit number of genetic clusters was determined by calculating the logarithmic probability $\mathrm{LnP}(\mathrm{K})$ using the $\Delta \mathrm{K}$ method [82]. Threshold q-values of 0.2 were used as a criterion to separate hybrids and pure mussels [83]. Individuals were considered residents if their q values were higher than 0.8 in the area where they were sampled. Individuals with q-values from 0.2 to 0.8 were considered to be potentially admixed, since they could not be readily assigned as residents or migrants [84]. A Markov chain Monte Carlo simulation was run for 100,000 iterations following a burn-in period of 50,000 iterations.

Correspondence analysis (CA) [85] implemented in GENETIX [86], was used to visualize the genetic substructure at the population and individual levels. The results are presented as a scatter plot, with the axes representing the contribution of inertia of the data matrix in a way that is analogous to the total variance in allelic frequency. Genetic assignment was obtained by using two methods. Following the STRUCTURE analysis, each individual was assigned with high confidence when q was higher or equal to 0.8 for a single cluster. In the second method, assignment of individuals to population of origin was obtained by using the frequency criteria on the basis of multilocus genotype data [87] in a self-assignment test with the leave-one-out (LOO) procedure implemented in GeneClass2.0 [88]. Individuals were considered to be correctly assigned to their location of origin if the assignment probability to that group was higher than any other assignment probability to any other group.

Following preliminary analyses that indicated that the Argentinian population of Puerto Madryn (PMD) contained possible hybrids, the software NewHybrids v1 [89] was used to estimate the posterior probability that individuals from PMD fell into each of the six genotypic categories (or classes corresponding to hybrid categories): native M. platensis, M. galloprovincialis, F1 hybrids, F2 hybrids and two types of backcrosses.

\section{Results \\ SNP validation, genetic diversity and Hardy-Weinberg equilibrium}

Of the 79 SNPs assayed, 55 were successfully genotyped with an acceptable quality score, and among these, 51 were polymorphic for 562 mussels from 19 samples [see Additional file 1: Table S1]. Of these 51 SNPs, 46 (90.2\%) were located in coding regions, among which only three were non-synonymous and five $(9.8 \%)$ were located in non-coding regions. Six loci were polymorphic in mussels from all samples [see Additional file 2: Table S2]. MAF per locus ranged from 0 to 0.362 (BM32A) with a mean $( \pm$ SD) of $0.078 \pm 0.091$ across all loci. Only five loci in single populations were not in Hardy-Weinberg equilibrium (HWE) after correction for multiple testing.

$F_{\mathrm{ST}}$ values at individual SNPs ranged from 0.014 to 1 [see Additional file 1: Table S1]. Twenty-three SNPs had $F_{\mathrm{ST}}$ values significantly different from zero. Several groups of samples were tested to detect highly informative SNPs that are effective for differentiation between groups. Populations and individuals (hybrids) with an admixture of different groups (taxa) were excluded from the analysis. An outlier test was carried out for the group of eight populations from Argentina (without PMD and $\mathrm{UBC}$ ) and the group of reference samples from Chile, USA, Canada, Northern Ireland, Spain, Italy and New Zealand. The test indicated 14 outlier loci, of which seven were characteristic only for $M$. trossulus and seven (BM101A, BM106B, BM12A, BM151A, BM17B, BM21B and $\mathrm{BM} 6 \mathrm{C}$ ) that differentiated the Argentinian samples. These latter same seven SNPs were identified as outliers in a test between M. platensis and M. galloprovincialis samples.

Four SNPs were effective at differentiating between the Argentinian and Chilean populations, and among these, two were significant also in the outlier analysis (BM151A and BM21B) while BM203C and BM57A were new. Subsequently, an outlier test was carried out to detect SNPs that could differentiate populations from Argentina and M. edulis samples from America and Europe. This test highlighted six outlier SNPs (BM106B, BM12A, BM12C, $\mathrm{BM} 21 \mathrm{~B}, \mathrm{BM} 21 \mathrm{C}$ and BM5D), of which three had not been previously reported. These findings show that 19 SNPs are sufficient to differentiate Argentinian populations from those of all other regions and highlighted their distinct taxon status. Five SNPs were identified as highly informative $(\mathrm{P}<0.01)$ : BM106B, BM12A, BM151A, BM21B, and BM6C.

\section{Genetic diversity}

The proportion of polymorphic SNPs $\left(P_{o}\right)$ ranged from 29.4 to $60.8 \%$ between populations, the lowest proportions being observed in most of the Argentinian populations. The values of $P_{o}, H_{o}$, gene diversity within populations were highest for the Argentinian PMD population, in which individuals of mixed origin were observed (Table 1). Based on the $F_{\mathrm{IS}}$ measures (averaged across all polymorphic loci in each population), an excess of homozygotes was found only in one population from Argentina (COM) and two reference samples (IRD, KKAT).

Genetic variation and differentiation between populations We constructed a neighbour-joining tree based on $F_{\mathrm{ST}}$ distance measures to detect the genetic relationships 
within 19 samples [see Additional file 3: Figure S1]. This identified five groups of populations i.e. $M$. trossulus, $M$. edulis, Northern and Southern Hemisphere M. galloprovincialis, M. chilensis and M. platensis, and one sample (PMD) that exhibited admixture in the Mytilus taxa. The population from Ushuaia (UBC) clustered with M. chilensis. Internal branches were short between $M$. chilensis and $M$. platensis populations, whereas they were long between M. edulis and M. galloprovincialis populations. Pairwise $F_{\mathrm{ST}}$ values were significantly different from zero after FDR-BY correction between most pairs of samples (Fig. 2) and [see Additional file 4: Table S3]. The largest differences were observed between $M$. trossulus and southern M. galloprovincialis from Akaroa, New Zealand (reaching values as high as 0.84). Pairwise $F_{\mathrm{ST}}$ estimates between the seven populations from Argentina $(M$. platensis) were not significantly different from zero (0 to 0.025), which indicated that these seven populations are mostly homogenous.

\section{Population structure}

To characterize the population structure of Mytilus, correspondence analyses (CA) were carried out on 18 samples of M. edulis, M. galloprovincialis, M. chilensis and $M$. platensis, by excluding $M$. trossulus for higher resolution (Fig. 3). Figure 3 shows a clear separation between M. galloprovincialis and the other samples along axis 1 . M. platensis and M. chilensis individuals formed very tight groups, in contrast to the M. edulis, M. galloprovincialis and most PMD individuals, which displayed more dispersion. The PMD sample occupied a central position between all other samples and overlapped only with M. galloprovincialis from the Atlantic coast of Europe (CAM).

STRUCTURE analysis showed that the $\operatorname{LnP}(\mathrm{D})$ increase was largest (i.e. $\Delta \mathrm{K}$ was highest) for $K=3$, and then $K=5$. This result indicated that the best-fit number of genetic clusters was found for $K=3$, for which differentiation between clusters corresponding to $M$. trossulus,

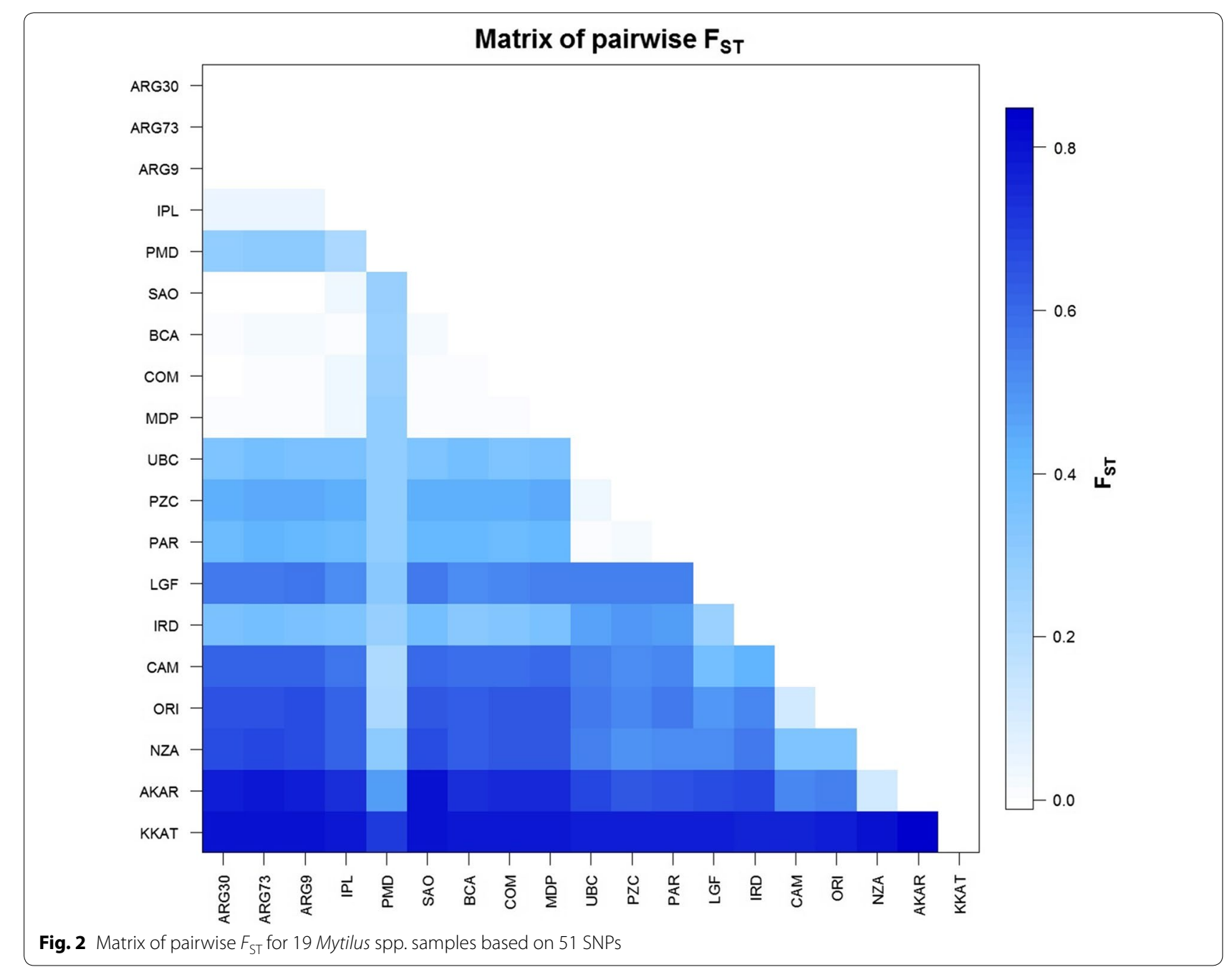




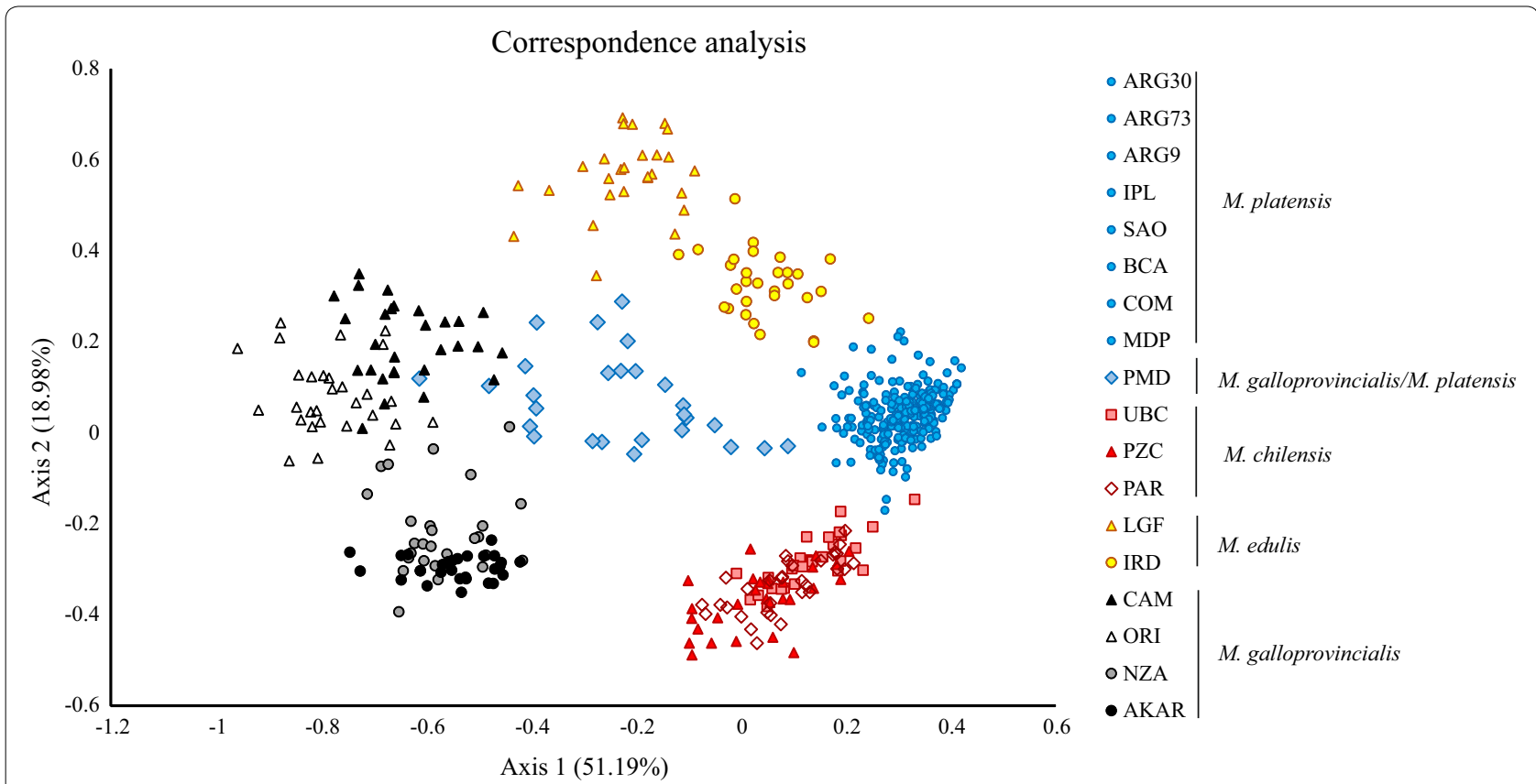

Fig. 3 The first two axes of the correspondence analysis (CA) computed from the SNP data on ten populations from Argentina and reference populations of M. edulis, M. galloprovincialis and M. chilensis from America, Europe and New Zealand. Each dot (point) is an individual

M. galloprovincialis and all other Mytilus taxa occurred. The high value of $\Delta \mathrm{K}$ for $K=5$ suggested further subdivision, with five clusters corresponding to five taxa: $M$. trossulus, M. galloprovincialis, M. edulis, M. chilensis and M. platensis (Fig. 4). These results confirmed the close relationship between $M$. edulis, $M$. chilensis and $M$. platensis taxa.

\section{Assignment of individuals}

Using the panel of 51 SNPs, two methods of analysis were used to test the assignment of individuals from Argentina to the most likely population and regions, based on reference taxa. In the STRUCTURE analysis at $K=5$, most of the 562 individuals were properly assigned to their original samples with a genome admixture value $\mathrm{q}$ higher than 0.8 [see Additional file 5: Table S4]. Eight populations from Argentina clustered together (M. platensis), whereas the sample from Ushuaia (UBC) clustered with the two $M$. chilensis samples from Chile. A few exceptions were observed: one individual from UBC was assigned to $M$. platensis, single individuals from ARG73 and IRD were considered potentially admixed $(M$. chilensis $\times M$. platensis and $M$. platensis $\times$ M. edulis, respectively). Furthermore, the entire PMD population from Argentina showed very high levels of admixture: one individual was assigned to M. galloprovincialis with q higher than 0.8 , whereas all other individuals were ambiguously assigned to two clusters, mainly to $M$. galloprovincialis and $M$. platensis, with q ranging from 0.2 to 0.8 . In addition, two individuals were assigned to two other clusters $M$. edulis and M. galloprovincialis, and M. chilensis and M. galloprovincialis. In general, most individuals had the highest q for the M. galloprovincialis cluster followed by the $M$. platensis cluster.

Individuals were assigned to baseline populations based on region of origin with a success rate of $97.8 \%$ using GeneClass2 [see Additional file 5: Table S4]. We performed a new (second) assignment analysis of the PMD population after removing the PMD sample from the baseline populations to identify the region of origin and found that $45 \%$ of the individuals from Puerto Madryn were assigned to $M$. galloprovincialis from the Mediterranean and Atlantic populations and more than $30 \%$ to the Argentinian population from Isla de los Pajáros (IPL). Four individuals were placed in the $M$. edulis population from North America and, for one individual the highest probability occurred for $M$. chilensis populations from Chile (PZC).

\section{Identification of hybrids}

Because most of the individuals from PMD were assigned mainly to two clusters using STRUCTURE analysis, $M$. platensis and Northern Hemisphere M. galloprovincialis, we carried out additional analyses to identify the type of hybrid (F1 or F2). Using the program NewHybrids, 19 SNPs that are effective at differentiating between 


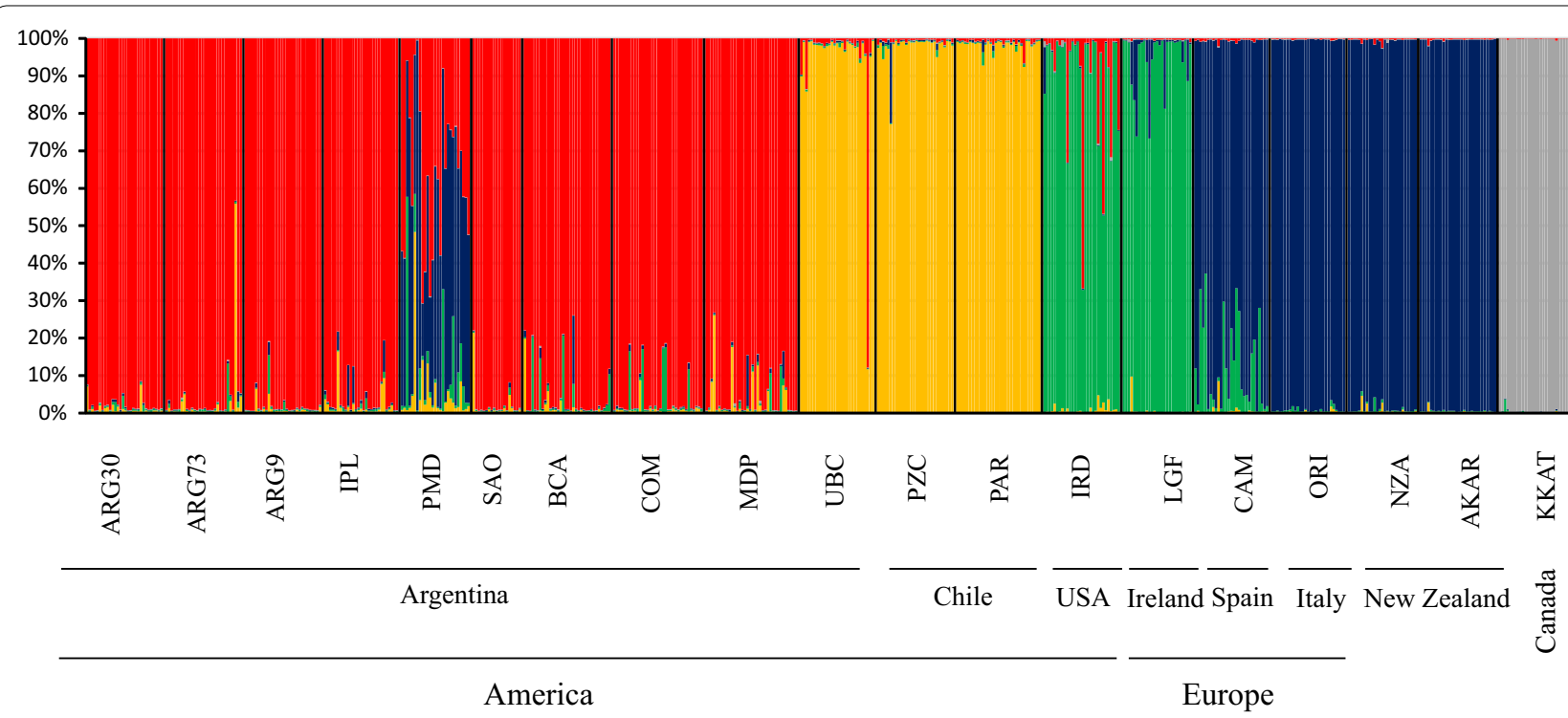

Fig. 4 Structure plots for the 19 studied populations $(K=5)$. Each individual is represented by a single vertical line broken into five coloured segments, with lengths proportional to each of the K inferred clusters. Abbreviation of the samples is provided in Table 1. Vertical black lines separate the populations

populations from Argentina were used to analyze all the Argentinian populations and three groups of reference samples: M. platensis, Northern Hemisphere M. galloprovincialis, and M. chilensis. All PMD individuals were identified as hybrids except one that was classified as $M$. galloprovincialis and F2 hybrids that carry M. platensis and M. galloprovincialis alleles were detected in $88.89 \%$ of the PMD individuals with a probability higher than $90 \%$. We did not identify any F1 hybrids and detected only one backcross (probability of $\sim 60 \%$ ) to M. platensis. In addition, using $M$. chilensis as a reference sample, two F2 hybrids that carry M. chilensis and M. galloprovincialis (PMD) alleles and M. chilensis and M. platensis (ARG73) alleles were identified.

\section{Identification of Mytilus taxa}

To determine the degree of similarity between taxa, we compared the different groups of populations without hybrids (admixture individuals). We constructed a NJ tree by using only non-admixed individuals as identified by STRUCTURE and GeneClass2 analysis, which revealed five well-supported clades that coincide with five separate taxa: $M$. trossulus, M. galloprovincialis, $M$. edulis, M. chilensis and M. platensis (Fig. 5). Based on pairwise $F_{\mathrm{ST}}$ values, $M$. platensis samples differed from $M$. chilensis samples $\left(F_{\mathrm{ST}}=0.421\right)$ and $M$. edulis samples $\left(F_{\mathrm{ST}}\right.$ ranging from 0.395 for American to 0.552 for European individuals) [see Additional file 6: Table S5]. $M$. platensis samples differed from Mediterranean $M$. galloprovincialis $\left(F_{\mathrm{ST}}=0.65\right)$. The level of differentiation observed between M. platensis and M. edulis was comparable to that between M. edulis and Atlantic M. galloprovincialis $\left(F_{\mathrm{ST}}=0.427\right.$, on average) and was highest between $M$. platensis and $M$. trossulus and Southern Hemisphere $M$. galloprovincialis taxa $\left(F_{\mathrm{ST}}\right.$ values as high as 0.797 ).

Overall, these results indicate that the samples of Mytilus in Argentina were composed of three groups: (1) eight samples of native $M$. platensis, (2) a southern group represented by the UBC population of native Chilean blue mussel (M. chilensis), and (3) the population from Puerto Madryn (PMD) composed of hybrid individuals (mostly between M. galloprovincialis and M. platensis). Argentinian populations showed a low level of hybridization, with the exception of the PMD population, which is composed mainly of hybrid individuals.

\section{Discussion}

In most previous studies of South American smoothedshelled blue mussel Mytilus populations e.g. [59, 68], only a small number of nuclear DNA markers, allozymes or mtDNA markers with limited resolution power was used. Recently, the efficiency of SNP analyses to study the genetic characteristics of hatchery and wild populations has been reported [90]. In our study, we carried out a thorough population genetic analysis and, for the first time, we show that Mytilus populations from the Atlantic coast of South America and Isla Grande de Tierra del Fuego are strongly differentiated and belong to at least three taxa. Native M. platensis is a separate taxon from 


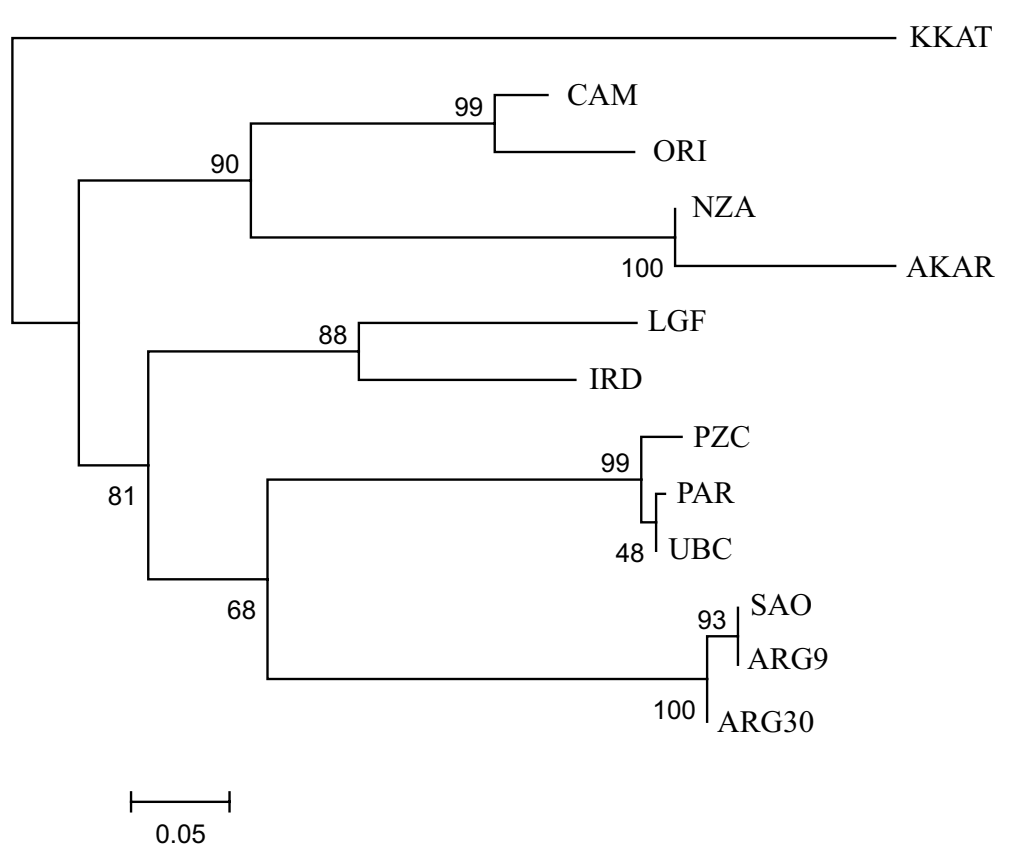

M. trossulus

M. galloprovincialis

M. edulis

M. chilensis

M. platensis

Fig. 5 Neighbour-joining tree of Mytilus spp. samples from Argentina and reference populations of M. edulis, M. trossulus, M. galloprovincialis and M. chilensis from America, Europe and New Zealand based on the $F_{S T}$ distance measures obtained with POPTREEW and visualised with MEGA version 6. $\mathrm{NJ}$ tree constructed using individuals without admixture $(q>0.8$ or $q<0.2)$ identified by STRUCTURE analysis $(K=5)$

other Mytilus species, including native M. chilensis. $M$. platensis predominates on the Argentinian coast south of Rio de La Plata, whereas $M$. chilensis inhabits the southernmost part of the South American coasts including the area of Isla Grande de Tierra del Fuego. Invasive European M. galloprovincialis and introgressed specimens were found in one location (PMD). These findings shed new light on the genetic relationships between South American Mytilus taxa. M. platensis was first described by d'Orbigny in 1846 [40] based on contemporary and paleontological samples that were collected from the area of Maldonaldo, Uruguay (Rio de la Plata) on the Atlantic coast. Based on ecological studies of coastal ecosystems and on toxicology analyses in fisheries and aquaculture of smooth shelled mussels, the presence of $M$. platensis (M. e. platensis) was reported on the Atlantic coast, from Uruguay including Maldonaldo in the north [45, 91-93] and at Mar del Plata on artificial reefs [94] to Golfo San Matias, Bahía San Julián, Santa Cruz Province and the Rio Gallegos Estuary, Patagonia, in the south [51, 54, 95, 96]. Furthermore, occurrence of M. chilensis (M. e. chilensis) on the Argentinian coast of the Isla Grande de Tierra del Fuego including the Ushuaia Bay was tentatively assumed from studies on similar topics [97-99].

In our study, we detected only one native individual $M$. chilensis $\times M$. platensis hybrid and one $M$. platensis $\times M$. edulis hybrid in more northern sampling sites. Oyarzún et al. [66] reported the occurrence of large numbers of hybrids between M. chilensis and native Atlantic Mytilus in the Magellan Region (southern Chile). However, since they used molecular markers with lower diagnostic power for Southern Hemisphere Mytilus taxa, their results cannot be directly compared with those reported here. We observed no hybridization in populations of $M$. chilensis from neighbouring sampling sites (Punta Arenas and Ushuaia) and detected only pure individuals of $M$. chilensis and one M. platensis individual in the area of the Isla Grande de Tierra del Fuego.

Based on the use of single molecular markers, hybridization of invasive Northern Hemisphere M. galloprovincialis with Southern Hemisphere native mussels in Chile, New Zealand and Australia was reported [28, 99, $100]$ and recently confirmed using SNP genotyping for populations from New Zealand and Chile [29, 31]. We used almost the same set of SNPs to investigate ten populations from Argentina. Our findings point to a local invasion and colonization event. No deficiency of heterozygotes was found within the PMD population, which suggests the absence of reproductive barriers. This contrasts with analyses on hybrid populations from Scotland, Barents Sea, Norway and Greenland for which there is a deficiency of heterozygotes $[14,20]$.

The introduction of $M$. galloprovincialis from the Northern Hemisphere might be related to past 
aquaculture activities in the Nuevo Gulf, although Dellatorre et al. [51] clearly stated that the cultivated mussels in a long-line system in Argentina originate from a natural settlement of M. e. platensis. In addition, the National authorities in Argentina did not issue any permission for any experiment related to the introduction of M. galloprovincialis (Marcela Alvarez, Subsecretaría de Pesca de la Nación, personal communication). It was further confirmed that no related aquaculture experiments were performed in Argentina (Mario Lasta, Instituto Nacional de Investigación y Desarrollo Pesquero, Mar Del Plata, personal communication). Another more likely scenario is the accidental introduction of M. galloprovincialis by means of ship transportation. Fishing vessels as well as big cruise ships enter Puerto Madryn from Europe, North America and Chile [101] with the problems of biofouling (accumulation of aquatic microorganisms, plants and animals on hull submerged surfaces) and the discharge of ballast waters [102], which releases these organisms in the environment. A previous study reported a high percentage of exotic and invasive species including unidentified Mytilus sp. in the Puerto Madryn local ecosystem [103]. For example, the Mytilid Semimytilus algosus was transported to Puerto Madryn (Nuevo Gulf) by a fishing vessel and released during in-water hull cleaning [104], which constitutes an example of introduction of a species similar to M. galloprovincialis.

The presence of Southern Hemisphere M. galloprovincialis was detected in Punta Arenas and named M. galloprovincialis planulatus Lmk 1819 [57]. However, Lamarck [105] originally described M. planulatus from Port du Roi George, Nouvelle-Hollande (present day Albany, Australia) in 1819. To confirm or not its occurrence in South America, new genetic markers such as SNPs could be used. However, our results did not confirm its presence in the studied area and a study of Mytilus populations from Chile, including Punta Arenas did not detect it [31]. Therefore, there is no evidence supporting the potential existence of M. planulatus in South America [68].

\section{Conclusions}

We have demonstrated that M. platensis (or M. e. platensis) and $M$. chilensis are differentiated and native taxa in South America, which indicates a distinct evolutionary history of Mytilus taxa from the Atlantic and Pacific coasts. Our analysis identified 19 SNPs (five of which are highly informative) that are effective in differentiating populations from Argentina. M. platensis is endangered by hybridization with the introduced European M. galloprovincialis in one area in Argentina (Puerto Madryn), presumably due to accidental introduction from ship traffic. We also confirmed the occurrence of $M$. chilensis on the Isla Grande de Tierra del Fuego, southern coast of Argentina. Knowledge of the origin of the mussels is very important for the conservation of native populations in the context of aquaculture activities in this area. The occurrence of the M.platensis $\times$ M. galloprovincialis hybrid population in Puerto Madryn that demonstrates one of the most invasive species, Northern Hemisphere M. galloprovincialis, is a threat to native populations. Continued monitoring is needed to check for the spread between these two taxa on the Atlantic coast of South America.

\section{Additional files}

Additional file 1: Table S1. SNP polymorphisms in populations of Mytilus spp. studied. Description: Information is presented on SNP properties, genome location, substitution type, $F_{\mathrm{ST}} P$ value associated with test for outlier status, minor allele frequency, GenBank annotation and references.

Additional file 2: Table S2. Allele frequencies of 51 SNPs for 19 Mytilus spp. sample. Description: The data show frequencies of all alleles at the studied SNP loci in all samples.

Additional file 3: Figure S1. Neighbour-joining tree of native South American and the reference Mytilus taxa. Description: Neighbour-joining tree shows genetic relationship between 19 Mytilus spp. samples from Argentina and reference populations of M. edulis, M. trossulus, M. galloprovincialis and M. chilensis from America, Europe and New Zealand based on the $F_{\text {ST }}$ distance measures obtained with POPTREEW and visualised with MEGA version 6

Additional file 4: Table S3. $F_{\mathrm{ST}}$ distance matrix for 19 Mytilus spp. samples for 51 SNPs. Description: Values of $F_{\text {ST }}$ with $P<0.05$ after BenjaminiYekutieli (FDR-BY) correction are marked in bold. Site names and locations are in Table 1.

Additional file 5: Table S4. Result of population assignment algorithms STRUCTURE and GeneClass for 19 populations of mussels. Description: Two methods of analysis were used to test the assignment of individuals from Argentina to the most likely population and regions, based on reference taxa. In the STRUCTURE analysis at $K=5$, most individuals were properly assigned to their original samples. Individuals were assigned with GeneClass 2 to baseline populations based on region of origin with a success rate of $97.8 \%$.

Additional file 6: Table S5. $F_{S T}$ distance matrix for Mytilus spp. samples. Description: $F_{\mathrm{ST}}$ distance matrix is presented for Mytilus spp. samples from Argentina and reference populations of M. edulis, M. trossulus, M. galloprovincialis and $M$. chilensis, obtained with POPTREEW for individuals without admixture $(q>0.8$ or $q<0.2)$ identified by STRUCTURE analysis.

\section{Authors' contributions}

RW, MIT and MZ participated in the design of the study. MIT organized sampling. MZ conducted part of the molecular work. MZ analyzed the data. RW conceived the study and coordinated the work. MZ, MIT and RW wrote the manuscript. All authors read and approved the final manuscript.

\footnotetext{
Author details

${ }^{1}$ Institute of Oceanology, Polish Academy of Sciences, Powstańców Warszawy 55, 81-712 Sopot, Poland. ${ }^{2}$ Instituto Nacional de Investigación y Desarrollo Pesquero, Paseo Victoria Ocampo No. 1, B7602HSA Mar Del Plata, Buenos Aires, Argentina.
}

\section{Acknowledgements}

This research was funded in part by the 2011/01/B/NZ9/04352 NCN Project to RW and statutory topic IV in the IOPAS. The authors thank Constanza Hozbor, Ronaldo Díaz, Ricardo Lopec, Pablo Izzo, Juan Pablo Simonazzi, Cristian 
Nivollet, Manuel García Penoni, Martín Díaz, Juan Pablo García and Stéphane Sorroche for collecting Argentinian mussel samples.

\section{Competing interests}

The authors declare that they have no competing interests.

\section{Consent for publication}

All authors have read and accepted the paper.

\section{Ethics approval and consent to participate}

This study was performed in accordance with the three Rs for the humane use of animals in scientific research.

\section{Publisher's Note}

Springer Nature remains neutral with regard to jurisdictional claims in published maps and institutional affiliations.

Received: 27 October 2017 Accepted: 31 January 2018

Published online: 22 February 2018

\section{References}

1. Kamermans P, Galley T, Boudry P, Fuentes J, McCombie H, Batista FM, et al. Blue mussel hatchery technology in Europe. In: Allan G, Burnell G, editors. Advances in aquaculture hatchery technology. Oxford: Woodhead Publishing; 2013. p. 339-73.

2. FAO. Fisheries and Aquaculture Department. Cultured aquatic species information programme: Mytilus edulis (Linnaeus, 1758). http:// www.fao.org/fishery/culturedspecies/Mytilus_edulis/en\#tcNA00D6. Accessed 22 Jan 2018

3. Kijewski T, Wijsman JWM, Hummel H, Wenne R. Genetic composition of cultured and wild mussels Mytilus from The Netherlands and transfers from Ireland and Great Britain. Aquaculture. 2009;287:292-6.

4. Smaal AC. European mussel cultivation along the Atlantic coast: production status, problems and perspectives. Hydrobiologia. 2002:484:89-98.

5. Muehlbauer F, Fraser D, Brenner M, Van Nieuwenhove K, Buck BH, Strand $O$, et al. Bivalve aquaculture transfers in Atlantic Europe. Part A: Transfer activities and legal framework. Ocean Coast Manag. 2014:89:127-38.

6. Geller J. Decline of a native mussel masked by sibling species invasion. Conserv Biol. 1999;13:661-4

7. Väinölä R, Hvilsom MM. Genetic divergence and a hybrid zone between Baltic and North Sea Mytilus populations (Mytilidae: Mollusca). Biol J Linn Soc. 1991:43:127-48.

8. Zbawicka M, Wenne R, Skibinski DOF. Mitochondrial DNA variation in populations of the mussel Mytilus trossulus from the Southern Baltic. Hydrobiologia. 2003;499:1-12.

9. Zbawicka M, Sanko T, Strand J, Wenne R. New SNP markers reveal largely concordant clinal variation across the hybrid zone between Mytilus spp. in the Baltic Sea. Aquat Biol. 2014;21:25-36.

10. Wennerström L, Laikre L, Ryman N, Utter FM, Ab Ghani NI, André C, et al. Genetic biodiversity in the Baltic Sea: species-specific patterns challenge management. Biodivers Conserv. 2013;22:3045-65.

11. Bierne N, Daguin C, Bonhomme F, David P, Borsa P. Direct selection on allozymes is not required to explain heterogeneity among marker loci across a Mytilus hybrid zone. Mol Ecol. 2003;12:2505-10.

12. Gilg MR, Hilbish TJ. Patterns of larval dispersal and their effect on the maintenance of a blue mussel hybrid zone in southwestern England. Evolution. 2003;57:1061-77

13. Dias PJ, Sollelis L, Cook EJ, Piertney SB, Davies IM, Snow M. Development of a real-time PCR assay for detection of Mytilus species specific alleles: application to a sampling survey in Scotland. J Exp Mar Biol Ecol. 2008;367:253-8

14. Wenne R, Bach L, Zbawicka M, Strand J, McDonald JH. A first report on coexistence and hybridization of Mytilus trossulus and M. edulis mussels in Greenland. Polar Biol. 2016:39:343-55.
15. Riginos C, Cunningham CW. Local adaptation and species segregation in two mussel (Mytilus edulis $\times$ Mytilus trossulus) hybrid zones. Mol Ecol. 2005;14:381-400.

16. Filipowicz M, Burzyński A, Śmietanka B, Wenne R. Recombination in mitochondrial DNA of European mussels Mytilus. J Mol Evol. 2008;67:377-88

17. Zbawicka M, Skibinski DOF, Wenne R. Doubly uniparental transmission of mitochondrial DNA length variants in the mussel Mytilus trossulus. Mar Biol. 2003;142:455-60.

18. Zbawicka M, Wenne R, Burzyński A. Mitogenomics of recombinant mitochondrial genomes of Baltic Sea Mytilus mussels. Mol Genet Genomics. 2014;289:1275-87.

19. Śmietanka B, Zbawicka M, Sańko T, Wenne R, Burzyński A. Molecular population genetics of male and female mitochondrial genomes in subarctic Mytilus trossulus. Mar Biol. 2013;160:1709-21.

20. Zbawicka M, Drywa A, Śmietanka B, Wenne R. Identification and validation of novel SNP markers in European populations of marine Mytilus mussels. Mar Biol. 2012;159:1347-62.

21. McQuaid CD, Phillips TE. Limited wind-driven dispersal of intertidal mussel larvae: in situ evidence from the plankton and the spread of the invasive species Mytilus galloprovincialis in South Africa. Mar Ecol Prog Ser. 2000;201:211-20.

22. Branch GM, Steffani CN. Can we predict the effects of alien species? A case-history of the invasion of South Africa by Mytilus galloprovincialis (Lamarck). J Exp Mar Biol Ecol. 2004;300:189-215.

23. Inoue K, Odo S, Noda T, Nakao S, Takeyama S, Yamaha E, et al. A possible hybrid zone in the Mytilus edulis complex in Japan revealed by PCR markers. Mar Biol. 1997;128:91-5.

24. Kartavtsev YP, Katolikova MV, Sharina SN, Chichvarkhina OV, Masalkova NA. A population genetic study of the hybrid zone of Mytilus trossulus Gould, 1850 and an introduced species, M. galloprovincialis Lamarck, 1819, (Bivalvia: Mytilidae) in Peter the Great Bay in the Sea of Japan. Russ J Mar Biol. 2014:40:208-16.

25. Saarman NP, Pogson GH. Introgression between invasive and native blue mussels (genus Mytilus) in the central California hybrid zone. Mol Ecol. 2015;24:4723-38.

26. Crego-Prieto V, Ardura A, Juanes F, Roca A, Taylor JS, Garcia-Vazquez E. Aquaculture and the spread of introduced mussel genes in British Columbia. Biol Invasions. 2015;17:2011-26.

27. Westfall KM, Gardner JPA. Genetic diversity of Southern hemisphere blue mussels (Bivalvia: Mytilidae) and the identification of non-indigenous taxa. Biol J Linn Soc. 2010;101:898-909.

28. Westfall KM, Gardner JPA. Interlineage Mytilus galloprovincialis Lmk. 1819 hybridization yields inconsistent genetic outcomes in the Southern hemisphere. Biol Invasions. 1819;2013(15):1493-506.

29. Gardner JPA, Zbawicka M, Westfall KM, Wenne R. Invasive blue mussels threaten regional scale genetic diversity in mainland and remote offshore locations: the need for baseline data and enhanced protection in the Southern Ocean. Glob Change Biol. 2016:22:3182-95.

30. Michalek K, Ventura A, Sanders T. Mytilus hybridisation and impact on aquaculture: a minireview. Mar Genomics. 2016;27:3-7.

31. Larrain MA, Zbawicka M, Araneda C, Gardner JPA, Wenne R. Native and invasive taxa on the Pacific coast of South America: impacts on aquaculture, traceability and biodiversity of blue mussels (Mytilus spp). Evol Appl. 2018. https://doi.org/10.1111/eva.12553 (Early view)

32. Klappenbach MA. Lista preliminar de los Myitilidae brasileños con claves para su determinación y notas sobre su distribución. Supl Anais Acad Brasil Cienc. 1965;37:327-52.

33. Castellanos ZJA. Contribución al estudio biológico del Mytilus platensis. Mar del Plata: Secretaría de Estado de Agricultura y Ganadería de la Nación; 1962. p. 1-29.

34. Amaro Padilla J. El mejillón de la bahía de Maldonado. Rev Inst Investig Pesq. 1967;2:81-94.

35. Toro JE, Castro G, Ojeda J, Vergara AM. Allozymic variation and differentiation in the Chilean blue mussel, Mytilus chilensis, along its natural distribution. Genet Mol Biol. 2006:29:174-9.

36. Ihering $\mathrm{H}$. Les mollusques fossiles du Tertiaire et du Crétacé Supérieur de l'Argentine. Buenos Aires: Anales del Museo Nacional de Buenos Aires; 1907. 
37. Carcelles A. Catálogo de los Moluscos Marinos de puerto Quequén (República Argentina). Rev Museo La Plata (Nueva Serie) Secc Zoología. 1944;3:233-309.

38. Soot-Ryen T. A report on the family Mytilidae (Pelecypoda). Allan Hancock Pacific Exped. 1955;20:1-175.

39. Castellanos ZA. Los mitilidos argentines. Buenos Aires: Ministerio de Agricultura y Ganaderia de la República Argentina, Departamento de Investigaciones Pesqueras; 1957. p. 5-12.

40. d'Orbigny A. Voyage dans l'Amérique méridionale (le Brésil, la république orientale de I'Uruguay, la république d'Argentine, la Patagonie, la république du Chili, la république de Bolivie, la république du Pérou), exécuté pendant les années 1826, 1827, 1828, 1829, 1830, 1831, 1832 et 1833. Vol. 5, Mollusques (1835-1843). Paris: P Bertrand. 1842; p. 758.

41. Hupé H. Moluscos de Chile. In: Gay C, editor. Historia fisica y politica de Chile. Zoologia, vol. 8. Paris: C Gay; 1854. p. 407.

42. Scarabino F. Lista sistemática de los bivalvia marinos y estuarinos vivientes de Uruguay. Comunicaciones de la Sociedad Malacológica del Uruguay. 2003;8:227-58.

43. Penchaszadeh PE. Estudios sobre el mejillón (Mytilus platensis d'Orb.) en explotación comercial del sector bonaerense. Mar Argentino. I. Reproducción, crecimiento y estructura de la población. Comisión Asesora Regional de Pesca para el Atlántico Sudoccidental: 22-25 Mar 1971, Mar del Plata; 1971. p. 12-5.

44. Penchaszadeh PE. Estructura de la comunidad y procesos que la determinan en bancos circalitorales de mejillón Mytilus platensis. Mem Sem Ecol Bent Sedim. Plata Cont. Atlántico Sur. Montevideo: UNESCO; 1979. p. 131-47.

45. Riestra G, Defeo O. Aspectos de la dinámica poblacional y estructura de la comunidad del mejillón Mytilus edulis platensis en la costa atlántica uruguaya. Publicaciones de la Comisión Técnica Mixta del Frente Marítimo (Uruguay). 1994;7:345-56.

46. Olivier SR, De Paternoster IK, Bastida R. Estudios biocenoticos en las costas de Chuhut (Argentina) I. Zonacion biocenologica de Puerto Pardelas (Golfo Nuevo). Bol Inst Biol Mar. 1966;10:1-74.

47. Zaixso HE, Pastor CT. Observaciones sobre la ecología de los mitílidos de la Ría Deseado. I. Distribución y análisis biocenótico. Ecosur. 1977:4:1-46.

48. Vinuesa JH. Ciclo gonadal y primera madurez sexual del mejillón patagónico Mytilus edulis chilensis hupe, en Puerto Deseado. Contribución Científica. 1979:150:35-47.

49. Bala LO. Biología y ecología del mejillón (Mytilus edulis platensis) en el Golfo San Jorge, provincia de Chubut. Ph.D. thesis, Universidad Nacional de La Plata; 1989.

50. Pascual MS, Zampatti E. Cultivo de Molucsos Bivalvos. In: Boschi EE, editor. El Mar Argentino y sus recursos pesqueros. 2. Los moluscos de interés pesquero. Cultivos y estrategias reproductivas de bivalvos y equinoideos. Instituto Nacional de Investigación y Desarrollo pesquero. Mar del Plata: Secretaría de Agricultura, Ganadería, Pesca y Alimentación; 1998. p. 167-93

51. Dellatorre FG, Pascual MS, Barón PJ. Feeding physiology of the Argentine mussel Mytilus edulis platensis (d'Orbigny, 1846): does it feed faster in suspended culture systems? Aquac Int. 2007;15:415-24.

52. Huidobro SP. Taller internacional: Unificando esfuerzos para el desarrollo de la acuicultura patagónica. Online presentation. 2015. http:// www.bioeconomia.mincyt.gob.ar/wp-content/uploads/2015/05/2_ElDesarrollo-Acu\%C3\%ADcola-visi\%C3\%B3n-de-la-DA.pdf. Accessed 23 Jan 2018

53. Huidobro SP. Producción por Acuicultura en Argentina en el 2016. Technical report; 2016. http://www.agroindustria.gob.ar/sitio/areas/ acuicultura/publicaciones/_archivos//000000_Informaci\%C3\%B3n\%20 y\%20noticias\%20vinculadas\%20al\%20sector/170605 Producci\%C3\%B3n\%20por\%20Acuicultura\%20en\%20Argentina\%20 durante\%20el\%20a\%C3\%B10\%202016.pdf. Accessed 23 Jan 2018

54. Narvarte M, González R, Filippo P. Artisanal mollusk fisheries in San Matías Gulf (Patagonia, Argentina): an appraisal of the factors contributing to unsustainability. Fish Res. 2007:87:68-76.

55. Bertolotti MI, Pagani A, Gualdoni P, Fosati J. Cadena de producción del cultivo del mejillón en el año 2011 en la Provincia de Tierra del Fuego, Antártida e islas del Atlantico Sur, Argentina. Revista Galega de Economía. 2014;23:33-50.
56. Toro JE, Ojeda J, Vergara AM, Castro GC, Alcapan AC. Molecular characterization of the chilean blue mussel (Mytilus chilensis Hupe 1854) demonstrates evidence for the occurrence of Mytilus galloprovincialis in Southern Chile. J Shellfish Res. 2005;24:1117-21.

57. Tarifeño E, Galleguillos R, Llanos-Rivera A, Arriagada D, Ferrada S, Canales-Aguirre CB, et al. Identificación errónea del mejillón, Mytilus galloprovincialis (Lamarck 1819) como la especie, Mytilus chilensis (Hupe 1854) en la Bahía de Concepción, Chile. Gayana (Concepción). 2012;76:167-72.

58. McDonald JH, Seed R, Koehn RK. Allozymes and morphometric characters of three species of Mytilus in the Northern and Southern hemispheres. Mar Biol. 1991;111:323-33.

59. Borsa P, Rolland V, Daguin-Thiebaut C. Genetics and taxonomy of Chilean smooth-shelled mussels, Mytilus spp. (Bivalvia: Mytilidae). C R Biol. 2012:335:51-61.

60. Daguin C, Borsa P. Genetic relationships of Mytilus galloprovincialis Lamarck populations worldwide: evidence from nuclear-DNA markers. In: Harper EM, Taylor JD, Crame JA, editors. The evolutionary biology of the bivalvia, vol. 177. London: Geological Society; 2000. p. 389-97.

61. Westfall KM, Wimberger PH, Gardner JPA. An RFLP mtDNA assay to determine if Mytilus galloprovincialis (Mytilidae: Bivalvia) is of Northern or Southern hemisphere origin. Mol Ecol Resour. 2010;10:573-5.

62. Cárcamo C, Comesaña AS, Winkler F, Sanjuan A. Allozyme identification of mussels (Bivalvia: Mytilus) on the Pacific coast of South America. J Shellfish Res. 2005;24:1101-15.

63. Astorga M. Estado actual de la genética de poblaciones del chorito $M$. chilensis en las costas chilenas. In: Astorga MP, Toro J, Martinez V, editors. Genética de mitílidos y su impacto en la mitilicultura. Puerto Montt Universidad Austral de Chile y Encubierta; 2012. p. 20-5.

64. Toro JE. PCR-based nuclear and mtDNA markers and shell morphology as an approach to study the taxonomic status of the Chilean blue mussel, Mytilus chilensis (Bivalvia). Aquat Living Resour. 1998;11:347-53.

65. Ouagajjou Y, Presa P, Astorga M, Pérez M. Microsatellites of Mytilus chilensis: a genomic print of its taxonomic status within Mytilus sp. J Shellfish Res. 2011;30:325-30.

66. Oyarzún PA, Toro JE, Cañete Jl, Gardner JPA. Bioinvasion threatens the genetic integrity of native diversity and a natural hybrid zone: smoothshelled blue mussels (Mytilus spp.) in the Strait of Magellan. Biol J Linn Soc. 2016;117:574-85.

67. Valenzuela A, Astorga MP, Oyarzũn PA, Toro JE. Caracterización genética de híbridos entre las especies Mytilus edulis platensis y Mytilus galloprovincialis (Mytilidae: Bivalvia) en la costa chilena. Lat Am J Aquat Res. 2016:44:171-6.

68. Astorga MP, Cardenas L, Vargas J. Phylogenetic approaches to delimit genetic lineages of the Mytilus complex of South America: how many species are there? J Shellfish Res. 2015;34:919-30.

69. Trucco MI. Diferenciación genética con polimorfismos alozímicos de Mytilus spp. del Atlántico Sudoccidental. Ph.D. thesis, Universidad de Vigo. 2001

70. Díaz C, Figueroa Y, Sobenes C. Seasonal effects of the seeding on the growth of Chilean mussel (Mytilus edulis platensis, d'Orbigny 1846) cultivated in central Chile. Aquaculture. 2014;428-429:215-22.

71. Molinet C, Díaz M, Marín SL, Astorga MP, Ojeda M, Cares L, et al. Relation of mussel spatfall on natural and artificial substrates: analysis of ecological implications ensuring long-term success and sustainability for mussel farming. Aquaculture. 2017;467:211-8.

72. Gaitán-Espitia JD, Quintero-Galvis JF, Mesas A, d'Elía G. Mitogenomics of southern hemisphere blue mussels (Bivalvia: Pteriomorphia): Insights into the evolutionary characteristics of the Mytilus edulis complex. Sci Rep. 2016:6:26853.

73. Hoarau G, Rijnsdorp AD, Van der Veer HW, Stam WT, Olsen JL. Population structure of plaice (Pleuronectes platessa L.) in northern Europe: microsatellites revealed large-scale spatial and temporal homogeneity. Mol Ecol. 2002;11:1165-76.

74. Gabriel S, Ziaugra L, Tabbaa D. SNP genotyping using the Sequenom MassARRAY iPLEX platform. Curr Protoc Hum Genet. 2009; Chapter 2: Unit 2.12.

75. Excoffier L, Lischer HEL. Arlequin suite version 3.5: a new series of programs to perform population genetics analyses under Linux and Windows. Mol Ecol Resour. 2010;10:564-7. 
76. Benjamini Y, Yekutieli D. The control of the false discovery rate in multiple testing under dependency. Ann Stat. 2001;29:1165-88.

77. Narum SR. Beyond Bonferroni: less conservative analyses for conservation genetics. Conserv Genet. 2006;7:783-7.

78. Takezaki N, Nei M, Tamura K. POPTREEW: web version of POPTREE for constructing population trees from allele frequency data and computing some other quantities. Mol Biol Evol. 2014;31:1622-4.

79. Tamura K, Stecher G, Peterson D, Filipski A, Kumar S. MEGA6: molecular evolutionary genetics analysis version 6.0. Mol Biol Evol. 2013;30:2725-9

80. Pritchard JK, Stephens M, Donnelly P. Inference of population structure using multilocus genotype data. Genetics. 2000;155:945-59.

81. Falush D, Stephens M, Pritchard JK. Inference of population structure using multilocus genotype data: dominant markers and null alleles. Mol Ecol Notes. 2007;7:574-8.

82. Evanno G, Regnaut S, Goudet J. Detecting the number of clusters of individuals using the software STRUCTURE: a simulation study. Mol Ecol. 2005:14:2611-20

83. Vähä JP, Primmer CR. Efficiency of model-based Bayesian methods for detecting hybrid individuals under different hybridization scenarios and with different numbers of loci. Mol Ecol. 2006;15:63-72.

84. Lecis R, Pierpaoli M, Biro ZS, Szemethy L, Ragni B, Vercillo F, et al. Bayesian analyses of admixture in wild and domestic cats (Felis silvestris) using linked microsatellite loci. Mol Ecol. 2006;15:119-31.

85. Benzécri JP. Correspondence analysis handbook. In: Balakrishnan N, Schucany WR, Garvey PR, editors. Statistics: a series of textbooks and monographs. New York: Marcel Dekker Inc.; 1992.

86. Belkhir K, Borsa P, Chikhi L, Raufaste N, Bonhomme F. GENETIX version 4.04, logiciel sous Windows ${ }^{\mathrm{TM}}$ pour la génétique des populations. Laboratoire Génome, Populations, Interactions: CNRS UMR 5000, Université de Montpellier II, Montpellier. 2003. http://kimura.univ-montp2.fr/ genetix/. Accessed 23 Jan 2018.

87. Paetkau D, Calvert W, Stirling I, Strobeck C. Microsatellite analysis of population structure in Canadian polar bears. Mol Ecol. 1995;4:347-54.

88. Piry S. GENECLASS2: a software for genetic assignment and first-generation migrant detection. J Hered. 2004;95:536-9.

89. Anderson EC, Thompson EA. A model-based method for identifying species hybrids using multilocus genetic data. Genetics. 2002;160:1217-29.

90. Wenne R. Single nucleotide polymorphism markers with applications in aquaculture and assessment of its impact on natural populations Aquat Living Resour. 2018;31:2.

91. Borthagaray Al, Carranza A. Mussels as ecosystem engineers: their contribution to species richness in a rocky littoral community. Acta Oecol. 2007;31:243-50

92. Hernandez G, Defeo O. Corporal mass-density relationship in a guild of benthic suspension feeders of the shallow rocky coast of two islands in Uruguay. Interciencia. 2005;30:711-6.
93. Niggemeyer F, Masello A. La pesqueria del mejillón (Mytilus edulis platensis): analisis de los desembarques en el Puerto de Punta del Este (Maldonado, Uruguay). Frente Maritimo. 1992;12A:3-8.

94. Genzano G, Giberto D, Bremec C. Benthic survey of natural and artificial reefs off Mar del Plata, Argentina, southwestern Atlantic. Lat Am J Aquat Res. 2011;39:553-6.

95. Lizarralde ZI, Pittaluga S. Distribution and temporal variation of the benthic fauna in a tidal flat of the Rio Gallegos Estuary, Patagonia, Argentina. Thalassas. 2010;27:9-20

96. Martin JP, Garese A, Sar A, Acuna FH. Fouling community dominated by Metridium senile (Cnidaria: Anthozoa: Actiniaria) in Bahia San Julian (southern Patagonia, Argentina). Sci Mar. 2015;79:211-21.

97. Amin OA, Comoglio LI, Sericano JL. Polynuclear aromatic and chlorinated hydrocarbons in mussels from the coastal zone of Ushuaia, Tierra del Fuego, Argentina. Environ Toxicol Chem. 2011;30:521-9.

98. Duarte CA, Giarratano E, Gil MN. Trace metal content in sediments and autochthonous intertidal organisms from two adjacent bays near Ushuaia, Beagle Channel (Argentina). Mar Environ Res. 2012;79:55-62.

99. Larrain MA, Diaz NF, Lamas C, Vargas C, Araneda C. Genetic composition of Mytilus species in mussel populations from southern Chile. Lat Am J Aquat Res. 2012;40:1077-84

100. Ab Rahim ES, Nguyen TTT, Ingram B, Riginos C, Weston KJ, Sherman $\mathrm{CDH}$. Species composition and hybridisation of mussel species (Bivalvia: Mytilidae) in Australia. Mar Freshw Res. 2016;67:1955-63.

101. Schwindt E, Gappa JL, Raffo MP, Tatian M, Bortolus A, Orensanz JM, et al. Marine fouling invasions in ports of Patagonia (Argentina) with implications for legislation and monitoring programs. Mar Environ Res. 2014;99:60-8

102. Prefectura Naval Argentina. Estadística Temporada de cruceros. Estadística de la APPM.2017. http://www.appm.com.ar/sites/default/files/ Estadistica_Cruceros.pdf. Accessed 23 Jan 2018.

103. Boltovskoy D, Almada P, Correa N. Biological invasions: assessment of threat from ballast-water discharge in Patagonian (Argentina) ports. Environ Sci Policy. 2011;14:578-83.

104. Bigatti G, Signorelli JH, Schwindt E. Potential invasion of the Atlantic coast of South America by Semimytilus algosus (Gould, 1850). Bio Invasion Rec. 2014;3:241-6.

105. de Lamarck JB. Histoire naturelle des animaux sans vertèbres présentant les caractères généraux et particuliers de ces animaux, leur distribution, leurs classes, leurs familles, leurs genres et la citation des principales espèces qui s'y rapportent, vol. 6. Paris: Librairie Verdière; 1819. p. 232.

\section{Submit your next manuscript to BioMed Central and we will help you at every step:}

- We accept pre-submission inquiries

- Our selector tool helps you to find the most relevant journal

- We provide round the clock customer support

- Convenient online submission

- Thorough peer review

- Inclusion in PubMed and all major indexing services

- Maximum visibility for your research

Submit your manuscript at www.biomedcentral com/submit 